DOI https://doi.org/10.30525/978-9934-26-047-6-25

\title{
ПРОТЕАЗНА АКТИВНІСТЬ В ЕМБРІОНАХ КОРОПОВИХ ВИДІВ РИБ НА РАННІХ СТАДІЯХ ОНТОГЕНЕЗУ ЗА РІЗНОГО ТЕМПЕРАТУРНОГО РЕЖИМУ ВОДОЙМИ
}

\author{
Потрохов О. С. \\ доктор біологічних наук, старший науковий співробітник, \\ завідувач відділу біології відтворення риб \\ Інститут гідробіології Наџіональної академії наук України
}

\section{Зіньковський О. Г.}

кандидат біологічних наук, старший науковий співробітник, провідний науковий співробітник відділу біології відтворення риб Інститут гідробіології Національної академії наук України

\section{Водяніцький О. М.}

кандидат біологічних наук, молодший науковий співробітник відділу біології відтворення риб Інститут гідробіології Наиіональної академії наук України м. Київ, Україна

Істотні коливання абіотичних чинників водного середовища спричиняє негативну дію на риб на всіх етапах їх розвитку. Ікра та личинки через те, що їх системи захисту знаходяться на стадії розвитку та не можуть покинути ділянки з несприятливими умовами, найбільш вразливі до їх дії. Нехарактерні температури, істотні зміни газового режиму викликають порушення поділу клітин, процесів диференціації органів та тканин, різноманітні ембріопатії та змінюють перебіг метаболічних процесів в ембріонів риб [1 с. 338-343, 2145 с.]. При цьому спостерігається тератогенез у риб, якій $\epsilon$ наслідком порушення у проходженні метаболічних процесів, зокрема і через зміни протеазної активності [5 p. 245-255, 6 р. 171-181]. Через кліматичні зміни, які спостерігаються останнім часом, в багатьох водоймах температура води збільшилась на $2-5^{\circ} \mathrm{C}$, спостерігаються іiі значні коливання протягом доби [7 p. 149-156].

Вивчення активності протеаз на ембріональних стадіях розвитку за дії екологічних чинників особливо важливо, оскільки саме на цих етапах відбувається суттєві перетворення у риб, створюються нові 
тканини та органи. Збільшення або зменшення активності протеаз також, в значній мірі, пов'язано з фізіологічними змінами ембріонів в період метаморфозу [4, р. 279-285].

Дослідження впливу абіотичних чинників на ранні етапи розвитку живих організмів є необхідною умовою для обгрунтування безпечних рівнів змін у навколишньому середовищі та буде сприяти прогнозуванню стану риб на нерестовищах, й, відповідно, розробки методів спрямованих на підвищення рибопродуктивності як в природних водоймах, так і у системах аквакультури.

Метою роботи було визначити вплив коливального режиму температури та концентрації розчиненого кисню у природній водоймі на протеазну активність зародків коропових риб протягом їх ембріонального розвитку.

Дослідження проводили на Білоцерківській експериментальній гідробіологічній станції Інституту гідробіології НАН України. Біологічним матеріалом досліджень були ікра та ембріони коропа (Cyprinus carpio L.), білого амура (Ctenopharyngodon idella Val.) та білого товстолобика (Hypophthalmichthys molitrix Val.).

Ікра риб утримувалася у сітчастих контейнерах та підлягала дії всіх абіотичних чинників середовища.

Активність протеаз (КФ 3.4) встановлювали імуноферментним методом за Тюриним та ін. [3-5 с.].

Встановлено, що на початкових стадіях розвитку ембріонів коропа (відділення хвоста) з підвищенням температурного режиму $320-23^{\circ} \mathrm{C}$ до $24-26^{\circ} \mathrm{C}$ активність протеаз зростає на $34,9 \%(\mathrm{p}<0,01)$. Проте, 3 подальшим підвищенням температури $\left(25-27^{\circ} \mathrm{C}\right.$ та $\left.28-32^{\circ} \mathrm{C}\right)$ активність ферментів знижувалася на 9,7-12,2\% $(\mathrm{p}<0,05)$. Слід зазначити, що до температури $26^{\circ} \mathrm{C}$ за умови достатнього насичення води розчинним киснем (5,0-7,2 мг/дм³ ${ }^{3}$ ембріони коропа на цій стадії розвитку розвивалися без патологій, життєздатність їх була вище за 85\%.

Подібна закономірність зберігалася і на наступній стадії розвитку рухливий ембріон. Максимальну активність ферменту було зафіксовано при температурі $24-26^{\circ} \mathrm{C}$ за достатнього насичення води киснем $\left(5,0-6,3\right.$ мг/дм $\left.{ }^{3}\right)$. За температурним режимом $28-32^{\circ} \mathrm{C}$ активність протеаз була мінімальною та нижче за $20-23^{\circ} \mathrm{C}$ на $36,7 \%(\mathrm{p}<0,01)$. Ембріони коропа при температурі оточуючого середовища вище $26^{\circ} \mathrm{C}$ максимально задіють свої резерви для пристосування до стресових умов, а при перевищенні межі температури за $30^{\circ} \mathrm{C}$ можливості 
протидіяти чиннику вичерпані. Це підтверджується утворенням великої кількості аномальних та нежиттєздатних зародків (до 30\%).

На стадії пігментація очей зберігається подібна закономірність.

Аналізуючи дані щодо активності протеаз протягом всього ембріогенезу, можна дійти наступних висновків: протягом всього ембріогенезу в досліджуваних режимах температур активність протеаз ембріонів коропа знаходилася на доволі високому рівні. Це свідчить про те, що ембріони коропа можуть розвиватися в широкому діапазоні температур. Характерним $\epsilon$ те, на початкових стадіях розвитку ембріоні протеазна активність більша при $24-26^{\circ} \mathrm{C}$, а для більш пізніх стадій розвитку та безпосередньо перед вилупленням передличинок $20-23^{\circ} \mathrm{C}$.

Ембріональний розвиток білого товстолобика триває значно менший період часу 32-36 год., порівняно з коропом (3,5-4,0 діб). За цей короткий час відбуваються необхідні процеси органогенезу та метаморфозу зародків, тому активність протеолітичних ферментів постійно змінюється залежно від етапів розвитку ембріонів.

На початкових стадіях розвитку білого товстолобика (кінець гаструляції) відмічається, що найкращою є температура води $24-26^{\circ} \mathrm{C}$. За цього температурного режиму спостерігалася максимальна активність протеаз (5,04 ум.од./мг білка×год), с подальшим підвищенням температури їх активність дещо знижувалася на 15,3-18,0\% (p<0,01) до 4,27 ум.од./мг білка×год. Це пояснюється тим, що ці стадії розвитку проходили в денні години та за достатнього насичення води киснем $\left(5,0-6,3\right.$ мг/дм $\left.{ }^{3}\right)$.

На стадії очні бокали зберігається подібна закономірність, як і на попередній стадії розвитку. Активність ферменту перебувала на високому рівні в усьому діапазоні температур від $22^{\circ} \mathrm{C}$ до $32^{\circ} \mathrm{C}-5,31-$ 3,98 ум.од./мг білка×год. відповідно. Максимальну активність було зафіксовано при температурі $24-26^{\circ} \mathrm{C}$, мінмальну $-28-32^{\circ} \mathrm{C}$. У найбільш прогрітій воді істотно підвищується утворення аномальних зародків (до 56\%) та знижується життєздатність ембріонов до $42 \%$.

Таким чином, за активністю протеаз можна оцінити фізіологічний стан ембріонів та встановити оптимальні межах абіотичних чинників для ебріонального розвитку. При перевищенні температурно оптимуму відбувається аномальний розвиток ембріонів. Оптимальними температурами для ембріонального розвитку білого товстолобик $є 24-26^{\circ} \mathrm{C}$.

Активність протеаз також чітко вказує вплив абіотичних чинників середовища на фізіологічний стан ембріонів білого амура, який теж має пелагічну ікру. Дуже добре прослідковується пряма залежність між активністю протеаз та температурою води на стадії кінця гаструляції. 
(рис. 1). Із збільшенням температурного режиму активність протеаз зростає. Мінімальну активність ферменту було зафіксовано при температурі води $20-23^{\circ} \mathrm{C}-4,26$ ум.од./мг білка×год., а максимальну при $28-32^{\circ} \mathrm{C}$, що в 2,4 рази більше.

Білий амур, кінець гаструляції

Активність протеаз $=-15,36+0,86671 *$ температура води

Correlation: $r=0,95903$

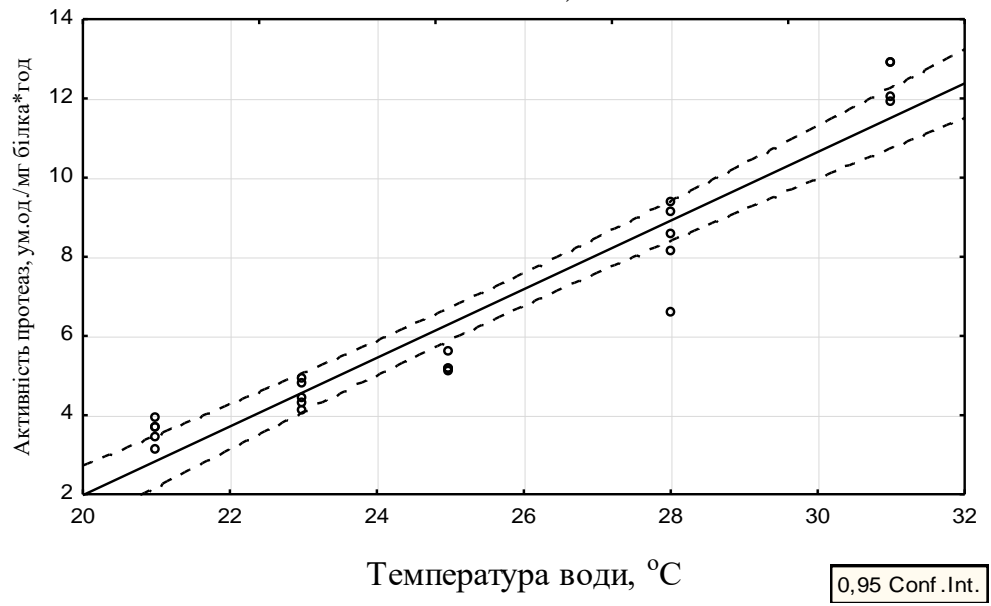

Рис. 1. Кореляційна залежність між температурою води та активністю протеаз в ікрі білого амура на стадії кінець гаструляції

На наступній стадії розвитку (очні бокали) загальна активність ферменту дещо знижувалася порівняно 3 попередньою стадією розвитку - на $23 \%$ при температурі $20-23^{\circ} \mathrm{C}$ та на $60,8 \%$ при $28-32^{\circ} \mathrm{C}$. Максимальну активність протеаз було зафіксовано при температурі $24-26^{\circ} \mathrm{C}$.

Таким чином, для білого амура на початкових стадіях розвитку характерна більш висока активність протеаз порівняно з наступною стадією. Але однією з причин подальшого аномального розвитку ембріонів за високих температур води може бути надмірна активність ферментів саме на стадії кінець гаструляції. Так, на стадії очних бокалів відбувається зниження життєздатності ембріонів на 28\% та утворюються їх аномалії (до 39\%) при температурному режимі 28 $32^{\circ} \mathrm{C}$. Проте ембріони білого амура більш пристосовані до істотного підвищення температури води, ніж білий товстолобик. Зі всього об'єму даних можна стверджувати, що температура води $24-26^{\circ} \mathrm{C} \epsilon$ 
найкращою для ембріонального розвитку білого амура, але за наявності достатньої кількості розчиненого кисню.

\section{Література:}

1. Журавлёва Н.Г. Влияние абиотических и биотических факторов среды на выживаемость эмбрионов и молоди рыб. Вестник МГТУ. 2009. T. 12 (2). 338-343.

2. Лукиянов С.В. Влияние колебаний абиотических факторов ( $\mathrm{pH}$, соленость, температура) на рыб в эмбрионально-личиночный период развития. Саранск. 2010. 145 с.

3. Тюрин Ю.А., Куликов С.Н., Фассахов Р.С., Долбин Д.А., Баязитова Л.Т. Способ определения IgG-протеиназной активности. Пат. 2373538 РФ. 2009. Бюл. № 32.5 с.

4. Cuvier-Peres A., Kestemont P. Development of some digestive enzymes in Eurasian perch larvae Perca fluviatilis. Fish Physiology and Biochemistry. 2002. Vol. 24. 279-285.

5. Bermudes M., Ritar A.J. Effects of temperature on the embryonic development of thestriped trumpeter (Latris lineata Bloch and Schneider, 1801). Aquaculture. 1999. Vol. 176. 245-255.

6. Herzig A., Winkler $H$. The influence of temperature on the embryonic development of three cyprinid fishes, Abramis brama, Chalcalburnus chalcoidesmento and Vimba vimba. J. Fish Biol. Vol. 28. 1986. 171-181.

7. Janauer G.A. Aquatic Vegetation in River Flood plains: Climate Change Effects, River Restoration and Ecohydrology Aspects. Climate Change. Inferences from Paleoclimate and Regional Aspects. New York: Springir. 2012. 149-156. 